\title{
EVALUATION OF BIOGAS PRODUCTION FROM HOUSEHOLD AND FARM WASTES USING DRY AND WET FERMENTATION
}

\section{K. Elbakhshwan ${ }^{1}$, H. H. Mohamed ${ }^{2}$, A. Essa $^{3}$}

\section{ABSTRACT}

An experiment under laboratory scale was conducted in the Biogas Laboratory at Testing and Research Station of Tractor and Agriculture Machinery, Alexandria. The study was done to evaluate the biogas production rate and methane content $\left(\mathrm{CH}_{4}\right)$ for batch anaerobic digestion under two types of wastes (household and farm) at three levels of temperature (60, 40 and ambient ${ }^{\circ} \mathrm{C}$ ) using two fermentation types (wet and dry). The wastes were analyzed for chemical characteristics such as total solids, volatile solids, organic carbon, nitrogen, potassium and phosphorus percentage. The obtained results clear that:

1- The best temperature was $60{ }^{\circ} \mathrm{C}$, which gave the maximum biogas production rate $(6.75 \mathrm{~L} /$ day $)$, cumulative $(119.95 \mathrm{~L})$ and methane percentage (63.66\%) and minimum retention time (35 days). Followed by temperature of $40{ }^{\circ} \mathrm{C}$ and ambient temperature, respectively.

2- The best fermentation type was the wet fermentation (10\% TS), which gave the highest biogas production rate, cumulative and minimum retention time as compared with dry fermentation (30\% TS).

3- The farm wastes gave the highest biogas production rates, cumulative and minimum retention time compared with household wastes.

Key words: Organic wastes, dry anaerobic fermentation, biogas, digester.

\section{INTRODUCTION}

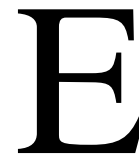
nergy maintains our entire economic system and supplies us with comfortable lives, for example, transports us, machines fuel and cooks our food. The amount of energy that fossil fuels could provide is ultimately limited. This means that the energy supply of the future needs solutions at the present.

1- Senior Researcher-Agricultural Engineering, Research Institute, Egypt.

2- Lecturer, Soil \& Ag. Eng. Dept., Fac of Agric. Saba Basha, Alexandria University, Egypt.

3- Demonstrator, Soil \& Ag. Eng. Dept., Fac of Agric. Saba Basha, Alexandria University, Egypt. 
For sufficient energy in future centuries, it is essential to further develop the utilization of renewable energy sources. Renewable energy resources can be defined as energy resources that are replaced rapidly by natural processes. It can be divided into geothermal, hydroelectric, solar, wave tidal, wind and biomass.

Biogas is an important source of renewable energy, which refers to a mixture of different gases produced by the breakdown of organic matter in the absence of oxygen. Biogas can be produced from raw materials such as agricultural waste, manure, municipal waste, plant material, sewage, green waste or food waste. It was produced by anaerobic digestion with anaerobic organisms, which digest material inside a closed system, or fermentation of biodegradable materials Jagadabhi (2011).

Methane is a rich energy source component in biogas and natural gas Energy map (2011). Biogas can be generated from a large numbers of raw materials and can be used for heat, power generation or as a vehicle fuel Lantz, et al. (2007). It could replace approximately 20 - 30\% of the natural gas consumption Khanal (2008).

Rashed (2014) reported that anaerobic digestion is a biological process, which occurs in the absence of oxygen. It helps in the breakdown of the organic matter and the stabilization of these materials, by conversion into $\mathrm{CH}_{4}$ and $\mathrm{CO}_{2}$ gases and a nearly stable residue. Biogas typically consists of $50-65 \%$ (volume) $\mathrm{CH}_{4}$ and $35-50 \%$ (volume) $\mathrm{CO}_{2}$.

Weilandp (2010) reported that Methane fermentation is a complex process, which can be divided up into four phases: hydrolysis, acidogenesis, cetogenesis (dehydrogenation), and methanation.

Karakashev, et al. (2005) reported that the digestion process takes place at mesophilic $\left(35-42{ }^{\circ} \mathrm{C}\right)$ or thermophilic $\left(45-60^{\circ} \mathrm{C}\right)$. It is important to keep a constant temperature during the digestion process, as temperature changes or fluctuations will affect the biogas production negatively.

Ošlaj and Bogomir (2010) reported that the livestock produce large quantities of waste materials, which is an excellent raw material for production of biogas. The quantity of biogas, which can be manufactured 
from various types of animal excrements and other agricultural wastes, depends on the organic matter content and the degree of decomposition of organic matter in the process of anaerobic fermentation.

Kuglarz et al. (2011) studied the dry fermentation of kitchen waste and chicken manure. Results vary a lot due to heterogeneity of food. In general, kitchen bio wastes are considered as good substrates for anaerobic digestion (AD), especially for co-digestion.

This research was carried out to:

1- Evaluate the biogas production from household and farm wastes using the dry and wet fermentation process.

2- Increase the production of biogas.

3- Decrease the hydraulic retention time for wastes.

\section{MATERIALS AND METHODS}

The experiments were conducted in the Biogas Laboratory of Testing and Research Station for Tractors and Agricultural Machinery, Alexandria. The chemical analysis was conducted in the laboratory of Soil and Agricultural Engineering dept.-Faculty of Agriculture (Saba Basha) Alexandria University.

\section{1-Materials}

\section{1-1-Wastes type}

The farme wastes consists of cattle dung, that were collected from cattle farm, while the household wastes samples were obtained from the remaining foods in the kitchen, such as potato, squash, orange, watermelon, tomato, cucumbers, lettuce, carrot, apple, bread and rice. The wastes were analyzed for chemical characteristic such as total Solids, volatile Solids, organic carbon, nitrogen, potassium and phosphorus percentage as shown in Table (1). To achieve the dry fermentation, cattle dung was used without adding water, while at wet digestion; water was added to the different prepared raw materials to form slurry of desired total solids concentration of $10 \%$ as recorded by Zennaki, et al., (1996). 
Table (1): Chemical analysis for cattle dung and household wastes.

\begin{tabular}{|c|c|c|}
\hline Characteristics & Cattle dung & Household wastes \\
\hline Moisture content, \% & 70.75 & 74.45 \\
\hline Total solids, $\%$ & 29.25 & 25.55 \\
\hline Total volatile solids, $\% \quad$ (T.V.S) & 52.58 & 78.98 \\
\hline Total organic carbon, $\%$ & 28.92 & 43.44 \\
\hline Ash, & 5.4 & 5.4 \\
\hline Total nitrogen, & 1.21 & 1.47 \\
\hline Carbon / Nitrogen ratio (C/N ratio) & 23.9:1 & 29.55:1 \\
\hline $\mathrm{PH}$ & 8.51 & 6 \\
\hline Potassium, $\%$ & 3.2 & 1.5 \\
\hline Phosphorus, \% & 0.53 & 0.51 \\
\hline
\end{tabular}

\section{1-2-The digesters:}

A six laboratory glass digesters were used to carry out twelve treatments. Each digester volume was 5 litres and connected with tow plastic Jars, one filled with water to receive the produced gas, and the other was empty to receive the displaced water as a result of biogas production. The volume of displaced water was equal to biogas production volume as shown in Fig. (1). Four digesters were installed inside water path which provided with electric heater $1200 \mathrm{~W}$ to keep the temperature at the desired level. The other two digesters were remained in the ambient temperature.
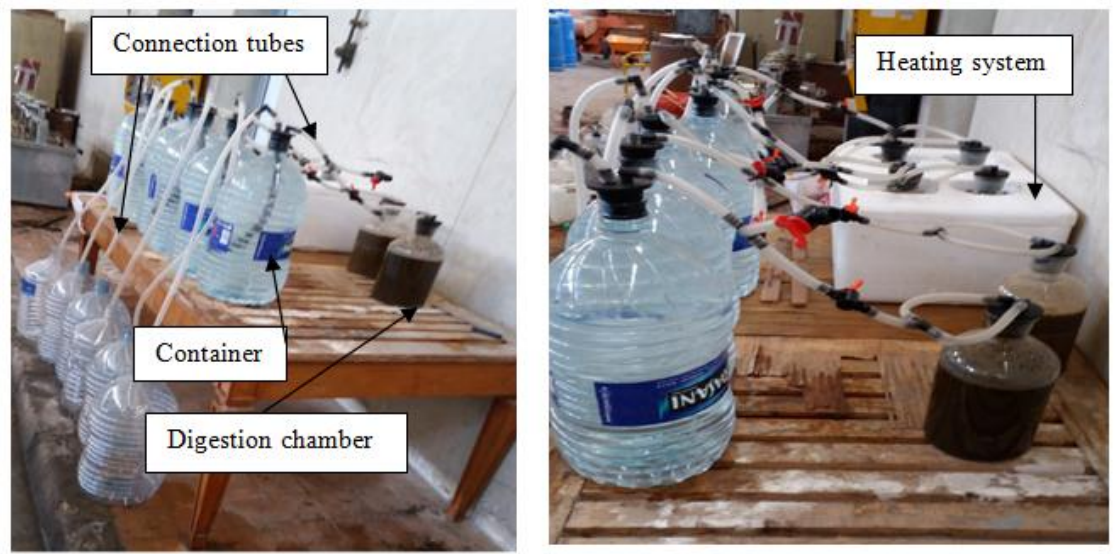

Fig. (1): Biogas digesters parts. 


\section{1-3- Instruments:}

1-3-1 The $\mathrm{pH}$ meter type of (daigger 5500) with ranged from 6.00 to 20 and an accuracy of $+/-0.01$ was used to measure the $\mathrm{pH}$ values for the organic waste

1-3-2 A Biogas analyzer (GA 5000) was used to measure the percentage of $\mathrm{CH}_{4}(0-100 \%), \mathrm{CO}_{2}(0-100 \%), \mathrm{O}_{2}(0-25 \%), \mathrm{H}_{2}(0-1000 \mathrm{ppm})$ and $\mathrm{H}_{2} \mathrm{~S}(0-10,000 \mathrm{ppm})$ in the biogas.

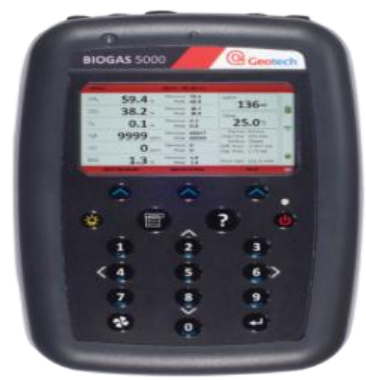

Fig. (2): Portable gas analyzer (GA5000).

1-3-3 The temperature of biogas digester was measured using thermometer in a range of $\left(0-100^{\circ} \mathrm{C}\right)$ with an accuracy of $1^{\circ} \mathrm{C}$.

1-3-4 A flow meter was used to measure volumetric flow rate of a biogas (liter per minute) with an accuracy of $+/-0.01$.

1-3-5 An electric oven was used to dry samples with temperature range of $40-250^{\circ} \mathrm{C}$ and accuracy of $1{ }^{\circ} \mathrm{C}$.

1-3-6 An incineration oven (wise therm) was used to incinerate samples with ranged from 300 to $1000{ }^{\circ} \mathrm{C}$ with an accuracy of $1^{\circ} \mathrm{C}$.

1-3-7 A flame photometer was used for determination of potassium (K).

1-3-8 A Spectro photometer was used to the routine determination of nitrogen $(\mathrm{N})$ and phosphorus $(\mathrm{P})$ in input and output material

\section{2- Methods:}

Laboratory experiments were carried out to evaluate the performance of the anaerobic digesters for producing biogas from organic wastes. All experiments were operated at $\mathrm{pH}$ ranged of 6-8 and retention times ranged from 40-75 days. The total solid of dry fermentation was about $30 \%$ TS, while the total solid of wet digestion was about $10 \%$. The 
amount of water required to adjust the total solids of slurry was calculated as follows according to Lo et al. (1981).

$$
D_{w}=R_{m}\left[\frac{T S_{m}-T S_{d i g}}{T S_{d i g}}\right]
$$

Where:

$\mathrm{D}_{\mathrm{W}}=$ dilution water required, $\mathrm{kg}$;

$\mathrm{R}_{\mathrm{m}}=$ amount of raw materials added, $\mathrm{kg}$;

$\mathrm{TS}_{\mathrm{m}}=$ total solid fraction of raw materials; $\%$ and, $\mathrm{TS}_{\mathrm{dig}}=$ total solids of fermentation materials, $\%$.

\section{2-1 Experimental conditions:}

Some different studying factors were experimented as shown in Fig. (3). The ambient temperature applied throughout these experiments was ranged from $20^{\circ} \mathrm{C}$ during the night time to $27^{\circ} \mathrm{C}$ during the day time.

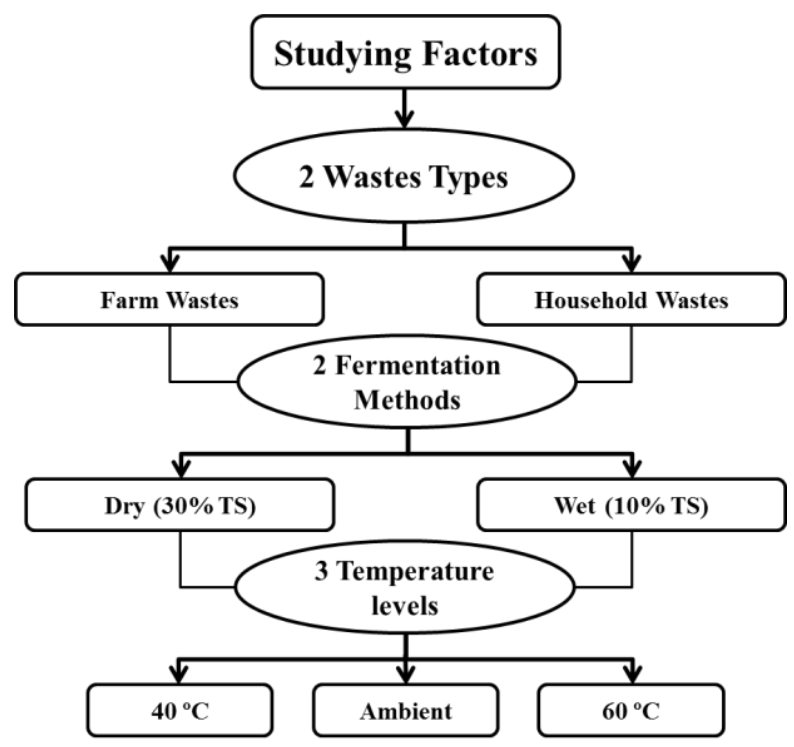

Fig.(3): Schematic diagram of factors under study.

\section{2-2-Assessments:}

\section{2-2-1 The daily biogas production:}

The daily biogas production was measured at atmospheric pressure by means of the acidified water displacement technique to prevent the dissolution of carbon dioxide contained in the biogas. It was then 
converted into standard conditions $\left(0^{\circ} \mathrm{C}\right.$ and 1013 mbar $)$ as mentioned by Gosch $\boldsymbol{e t}$ al. (1983) using the following equation:

$$
V_{t r}=\frac{V_{f}\left[273.15\left(P_{1}-P_{2}-P_{3}\right)\right.}{[273.15+T] \times 1013}
$$

Where:

$V t r=$ volume of dry gas under standard condition, liter;

$V f=$ volume of wet gas at pressure $\mathrm{P}$ and temperature $\mathrm{T}$, liter;

$T=$ temperature of wet gas, ${ }^{\circ} \mathrm{C}$;

$P 1=$ air pressure at temperature $\mathrm{T}$, millibar;

$P 2=$ pressure of wet gas at temperature T, millibar;

$P 3$ = saturation steam pressure of water at temperature $\mathrm{T}$, millibar;

$1013=$ absolute pressure in (millibar).

\section{2-2-2 Total energy production:}

The total energy production from all experiments was estimated according to Mitzalff (1988) as follows:

$$
\mathrm{TE}_{\mathrm{P}}=\mathrm{B}_{\mathrm{PR}} \times \mathrm{CH}_{4}(\%) \times \mathrm{CV} \text { of } \mathrm{CH} 4
$$

Where:

$\mathrm{TE}_{\mathrm{P}}=$ total energy production, $(\mathrm{MJ} /$ day $)$.

$\mathrm{B}_{\mathrm{PR}}=$ biogas production rate, $\left(\mathrm{m}^{3} / \mathrm{m}^{3} /\right.$ day $)$.

$\mathrm{CV}=$ calorific value of $\mathrm{CH} 4,\left(3.6 \mathrm{MJ} / \mathrm{m}^{3}\right)$.

$\mathrm{CH} 4=$ methane percent in biogas, $(\%)$

\section{RESULTS AND DISCUSSION}

This study was investigated to evaluate the biogas production rate and content of methane $\left(\mathrm{CH}_{4}\right)$ for dry and wet fermentation of farm and household wastes at temperatures of 60,40 and ambient ${ }^{\circ} \mathrm{C}$. The biogas production was determined at the standard conditions (STP).

\section{1- Effect of temperature:}

The effect of temperature on biogas production rate at wet and dry fermentation for different wastes was investigated. The obtained results were illustrated in Table (2) and Figs. (4 and 5).

The results indicated that the highest biogas production rate was at temperature of $60{ }^{\circ} \mathrm{C}$ at different wastes and digestion types followed by $40^{\circ} \mathrm{C}$ and ambient temperature respectively. 
The highest biogas production rate at temperature of $60{ }^{\circ} \mathrm{C}$ for wet digestion was 6.75 liter/day at the $15^{\text {th }}$ day for farm wastes, while was 3.45 liter/day in the $19^{\text {th }}$ day for household wastes. While these values at $40{ }^{\circ} \mathrm{C}$ were; 4.59 liter/day in the $18^{\text {th }}$ day for the farm wastes and 2.82 liter/day in the $27^{\text {th }}$ day for house hold wastes. The lowest value was 3.75 liter/day in the $31^{\text {th }}$ day for farm wastes and 2.22 liter/day in the $36^{\text {th }}$ day for household wastes at ambient temperature. The lowest retention time was 35 and 40 days at farm and household wastes respectively at the highest temperature of $60{ }^{\circ} \mathrm{C}$, followed by 46 and 53 days at $40{ }^{\circ} \mathrm{C}$ with the same wastes respectively. The highest retention time was 61 and 64 days for farm and household wastes respectively at ambient temperature.

The cumulative biogas production for wet digestion of farm wastes was 107.40, 118.65 and 119.95 liter at temperature of ambient, 40 and $60{ }^{\circ} \mathrm{C}$, respectively, while was $68.26,73.20$ and 74.40 liter at the same temperatures for household wastes respectively as showed in Fig (6).

The highest biogas production rate at temperature of $60{ }^{\circ} \mathrm{C}$ for dry fermentation was 4.73 liter/day at the $17^{\text {th }}$ day for farm wastes, while was 2.22 liter/day in the $23^{\text {th }}$ day at the same temperature for household wastes.
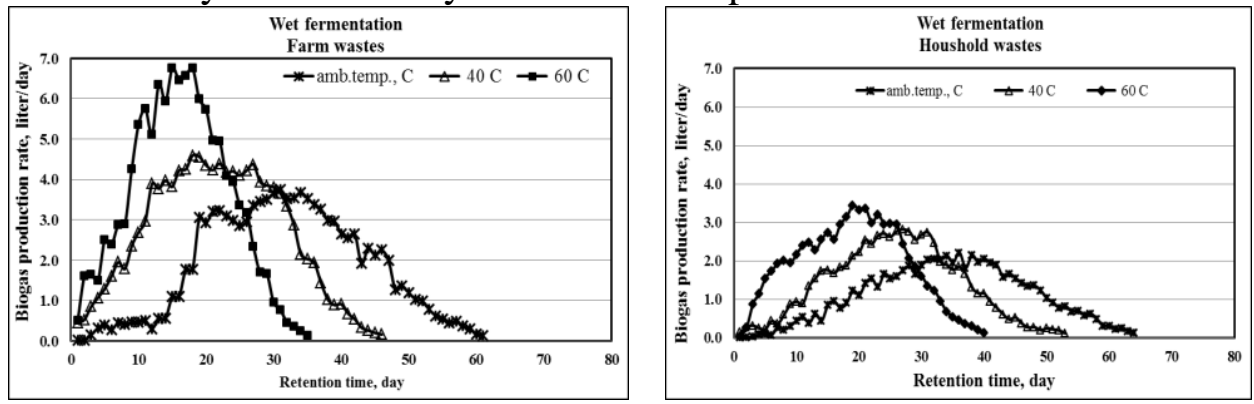

Fig.(4):Effect of temperature on daily biogas production by wet fermentation.
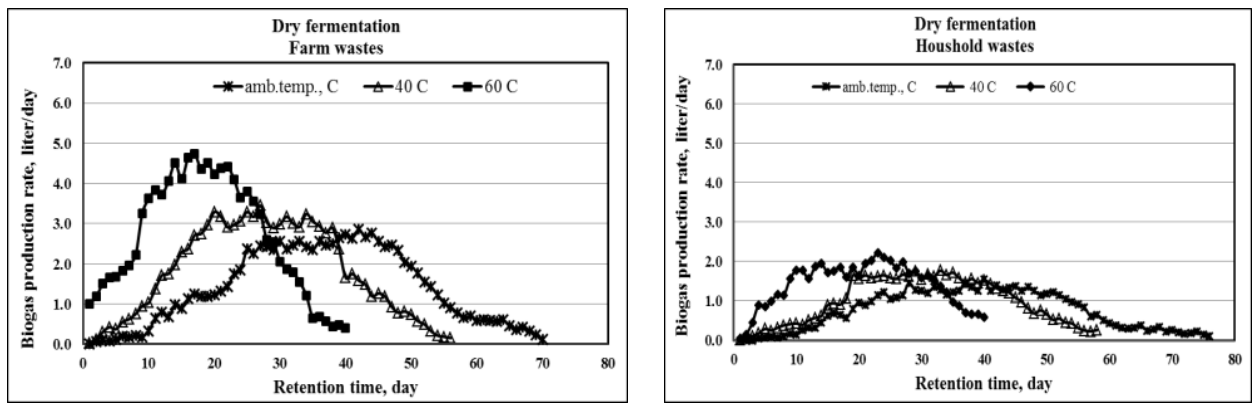

Fig.(5):Effect of temperature on daily biogas production by dry fermentation. 
Table (2): The effect of different temperatures, waste and fermentation types on biogas production rates and cumulative production and retention time.

\begin{tabular}{|c|c|c|c|c|c|}
\hline \multirow{2}{*}{$\begin{array}{c}\text { Waste } \\
\text { type }\end{array}$} & \multirow{2}{*}{$\begin{array}{c}\text { Digestion } \\
\text { type }\end{array}$} & Temp. & Retentio & Biogas & cumulative \\
\hline & & ${ }^{0} \mathrm{C}$ & day & Liter/day & Liter \\
\hline \multirow{6}{*}{$\begin{array}{c}\text { Farm } \\
\text { wastes }\end{array}$} & \multirow[t]{3}{*}{ Wet } & Ambient & 61 & 3.75 & 107.40 \\
\hline & & 40 & 46 & 4.59 & 118.65 \\
\hline & & 60 & 35 & 6.75 & 119.95 \\
\hline & \multirow[t]{3}{*}{ Dry } & Ambient & 70 & 2.55 & 96.59 \\
\hline & & 40 & 56 & 3.45 & 100.85 \\
\hline & & 60 & 43 & 4.73 & 107.15 \\
\hline \multirow{6}{*}{$\begin{array}{c}\text { Household } \\
\text { wastes }\end{array}$} & \multirow[t]{3}{*}{ Wet } & Ambient & 64 & 2.22 & 68.26 \\
\hline & & 40 & 53 & 2.82 & 73.20 \\
\hline & & 60 & 40 & 3.45 & 74.40 \\
\hline & \multirow[t]{3}{*}{ Dry } & Ambient & 76 & 1.55 & 56.10 \\
\hline & & 40 & 60 & 1.77 & 57.45 \\
\hline & & 60 & 47 & 2.22 & 58.35 \\
\hline
\end{tabular}

While these values at $40^{\circ} \mathrm{C}$ were; 3.45 liter/day in the $27^{\text {th }}$ day for farm wastes and 1.77 liter/day in the $33^{\text {th }}$ day for house hold wastes. The lowest value was 2.85 liter/day in the $42^{\text {th }}$ day for farm wastes and 1.55 liter/day in the $40^{\text {th }}$ day for household wastes at ambient temperature. The lowest retention time was 43 and 47 days for farm and household wastes respectively at temperature of $60{ }^{\circ} \mathrm{C}$. Moreover, at temperature of $40{ }^{\circ} \mathrm{C}$ these values were 56 and 60 days for the same wastes, respectively. The highest retention time was 70 and 76 days for farm and household wastes respectively at ambient temperature.

The cumulative biogas production for dry digestion of farm wastes was 96.60, 100.85 and 107.15 liter at temperature of ambient, 40 and $60{ }^{\circ} \mathrm{C}$, respectively, while was $56.10,57.45$ and 58.35 liter at same temperatures, respectively with household wastes as showed in Fig (7).

For all experiments the highest gas volume and the lowest retention time were at temperature of $60{ }^{\circ} \mathrm{C}$. This may be due to higher grow of thermophilic bacteria which lead to fast decomposition of organic substrates and then, increase the biogas production with decrease of the retention time. 

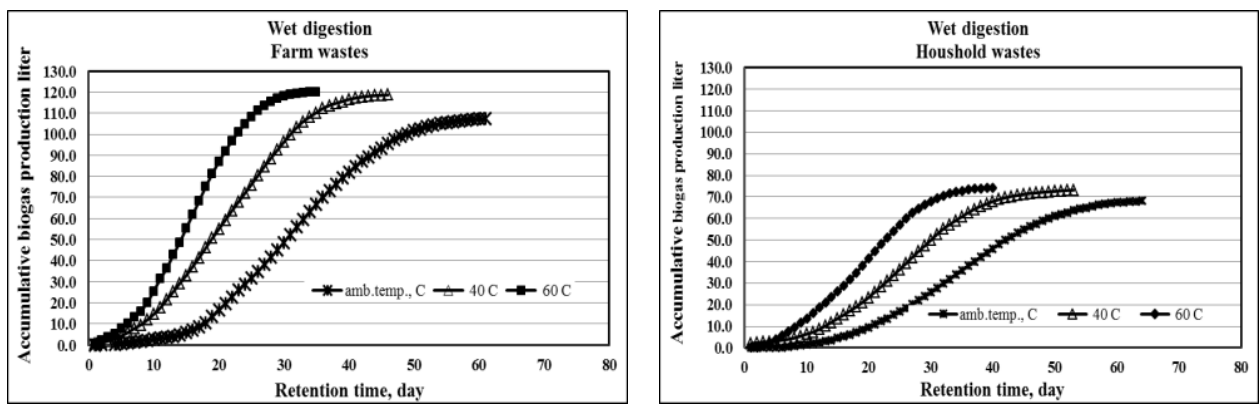

Fig.(6):Effect of temperature on cumulative biogas production at wet digestion.
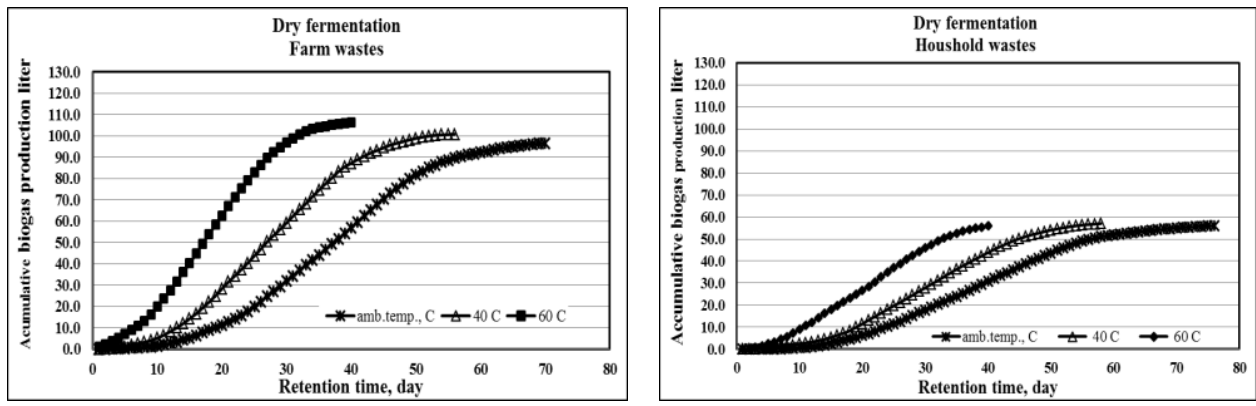

Fig.(7):Effect of temperature on cumulative biogas production at dry fermentation

The ambient temperature was gave the lowest biogas production as compared with the other two applied temperatures of 40 and $60{ }^{\circ} \mathrm{C}$. This is may be due to limit activities of microorganisms. The obtained results indicated that the biogas production rate was increase with increasing the digestion temperature.

\section{2- Effect of waste type:}

The farm wastes gave the highest biogas production rate at different temperatures and fermentation types compared with the household wastes as showed in Figs (8, 9 and 10).

The highest biogas production rates for farm wastes of wet fermentation was 6.75, 4.59, and 3.75 liter/day at temperature of 60, 40, and ambient temperature ${ }^{\circ} \mathrm{C}$ respectively, while was 3.45, 2.82, and 2.22 liter/day for household wastes at the same temperatures, respectively.

The highest biogas production rate for dry fermentation of farm wastes was 4.73, 3.45, and 2.85 liter/day at temperature of 60, 40 and ambient temperature ${ }^{\circ} \mathrm{C}$ respectively, while was $2.22,1.77$ and 1.55 liter/day for household wastes at the same temperatures respectively. 

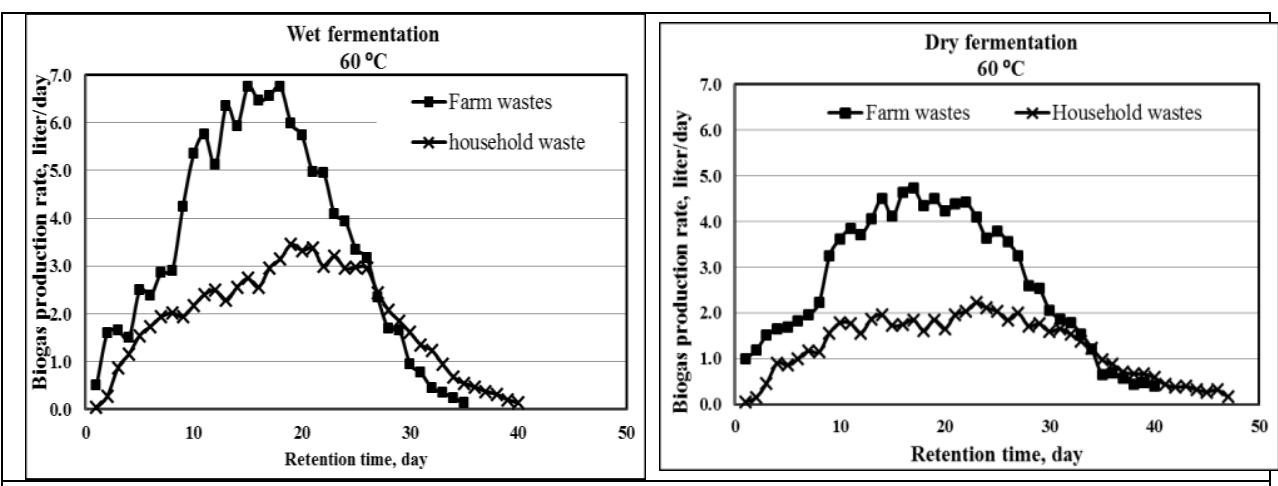

Fig.(8) : Effect of waste type on biogas production for wet and dry fermentation at temperatures of $60{ }^{\circ} \mathrm{C}$.
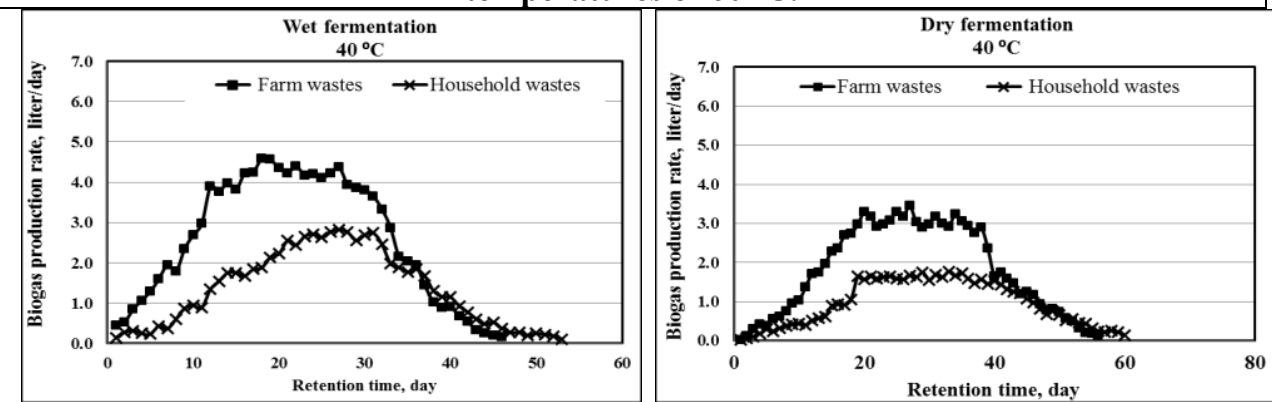

Fig.(9) : Effect of waste type on biogas production for wet and dry fermentation at temperatures of $40{ }^{\circ} \mathrm{C}$.
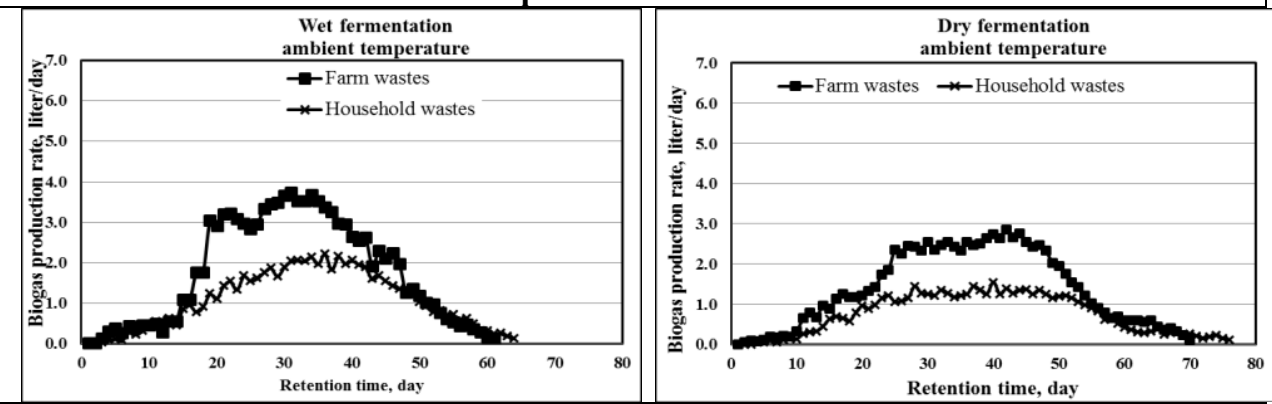

Fig.(10) : Effect of waste type on biogas production for wet and dry fermentation at ambient temperature.

The lowest retention time was 35 days for wet digestion of farm wastes at temperature of $60{ }^{\circ} \mathrm{C}$, while the highest retention time was 76 days for dry fermentation of household wastes at ambient temperature.

It was observed that the daily and cumulative biogas production for farm wastes was higher than household wastes for all experiments. This may be due to the farm wastes consist of cow manure, which is semi digested 
residue of plant matter which has passed through the animal's gut. The resultant matter is rich in minerals and bacteria, while household wastes consists of the undigested remains of food in the kitchen, so that fermentation microorganisms needs more time to digest the organic matter in house hold wastes to produce biogas. So it is better to produce the biogas from farm wastes.

\section{3- Effect of fermentation type}

The obtained results showed that, the wet fermentation gave higher biogas production rate, cumulative production and shorter retention time as compared with the dry fermentation for all temperatures and wastes. The highest biogas production rate was 6.75 liter /day with wet fermentation of farm wastes and temperature of $60{ }^{\circ} \mathrm{C}$, while the lowest value was 1.55 liter/day with dry fermentation of household wastes at ambient temperature. The highest and lowest cumulative biogas productions were 119.95 and 56.1 liter and they occurred at the same conditions and wastes, respectively as showed in Table (2).

On the other hand, the wet fermentation gave the shorter retention time of 35 days at farm wastes and temperature of $60{ }^{\circ} \mathrm{C}$ compared with 76 days at household wastes and ambient temperature.

\section{4- Effect of different studying factors on biogas compositions:}

The biogas composition is dependent on the type of feed stocks and to some extent on the technique used in the digestion process. The effects of temperature, waste types and fermentation type on biogas compositions were evaluated and the obtained results are listed in Table (3). It was observed that the highest methane percent was $63.66 \%$ at wet fermentation of farm wastes with temperature of $60{ }^{\circ} \mathrm{C}$, while the lowest methane percent was $49.3 \%$ at dry fermentation of house hold wastes with ambient temperature. On the other hand, the methane percentage in biogas production from farm wastes was higher than that production from household wastes. In addition, the wet fermentation process was gave higher methane content as compared with dry fermentation process. The results also, clear that there is no significant difference in methane content at different digestion temperatures but there were slight increase in methane content at temperature of $60{ }^{\circ} \mathrm{C}$ as compared with the other two temperatures. 
Table (3): Effect of wastes and fermentation types on biogas compositions at different digestion temperatures.

\begin{tabular}{|c|c|c|c|c|c|}
\hline \multirow[t]{3}{*}{ Waste type } & \multirow{3}{*}{$\begin{array}{c}\text { Digestion } \\
\text { type }\end{array}$} & \multirow[t]{2}{*}{ Temp } & \multicolumn{3}{|c|}{ Biogas compositions } \\
\hline & & & $\mathrm{CH}_{4}$ & $\mathrm{CO}_{2}$ & $\mathbf{H}_{2} \mathbf{S}$ \\
\hline & & ${ }^{0} \mathrm{C}$ & $\%$ & $\%$ & ppm \\
\hline \multirow[t]{6}{*}{ Farm wastes } & \multirow[t]{3}{*}{ Wet } & ambient & 63.35 & 36.65 & 19.33 \\
\hline & & 40 & 62.72 & 37.28 & 28.00 \\
\hline & & 60 & 63.66 & 36.34 & 11.33 \\
\hline & \multirow[t]{3}{*}{ Dry } & ambient & 61.23 & 38.77 & 20.60 \\
\hline & & 40 & 62.68 & 37.32 & 35.75 \\
\hline & & 60 & 61.98 & 38.02 & 12.25 \\
\hline \multirow{6}{*}{$\begin{array}{l}\text { Household } \\
\text { wastes }\end{array}$} & \multirow[t]{3}{*}{ Wet } & ambient & 52.90 & 47.10 & 33.00 \\
\hline & & 40 & 53.60 & 46.40 & 14.00 \\
\hline & & 60 & 54.21 & 45.79 & 17.20 \\
\hline & \multirow[t]{3}{*}{ Dry } & ambient & 49.30 & 50.70 & 29.00 \\
\hline & & 40 & 51.70 & 48.30 & 19.00 \\
\hline & & 60 & 52.01 & 47.99 & 22.30 \\
\hline
\end{tabular}

\section{CONCLUSIONS}

This study was done to evaluate the biogas production rate and methane content $\left(\mathrm{CH}_{4}\right)$ for batch anaerobic digestion under two types of wastes (household and farm) at three levels of temperature (60, 40 and ambient ${ }^{\circ} \mathrm{C}$ ) using wet and dry fermentation. This research was carried out to: evaluate the biogas production from household and farm wastes, increase the production of biogas and decrease the hydraulic retention time.

The maximum cumulative biogas production for wet fermentation of farm wastes was $119.95,118.65$ and 107.40 liter at temperature of 60, 40 and ambient ${ }^{\circ} \mathrm{C}$ respectively, while there were; 74.40, 73.20 and 68.26 liter for household wastes at the same temperature, respectively. These values for dry fermentation of farm wastes were; 107.15, 100.85 and 96.59 liter at the same temperatures, respectively, while there were; 58.35, 57.45 and 56.10 liter for household wastes. The minimum retention time was 35 days at temperature of $60^{\circ} \mathrm{C}$ with wet fermentation of farm wastes, while the maximum retention time was 76 days at ambient temperature ${ }^{\circ} \mathrm{C}$ with dry fermentation of household wastes. 
In general, the following conclusions can be summarized:

1- The best temperature was $60{ }^{\circ} \mathrm{C}$, which gave the maximum biogas production rate $(6.75 \mathrm{~L} /$ day $)$, cumulative $(119.95 \mathrm{~L})$ and methane percentage (63.66\%) and minimum retention time (35 days). Followed by temperature of $40{ }^{\circ} \mathrm{C}$ and ambient temperature, respectively.

2- The best fermentation type was wet fermentation (10\% TS), which gave the highest biogas production rate and cumulative and minimum retention time as compared with dry fermentation (30\% TS).

3- The farm a waste gave the highest biogas production rates and cumulative and minimum retention time compared with household wastes.

\section{REFERENCES}

APHA (American Public Health Association), (1989)."Standard methods for the examination of water and waste water". 17 th.ed. Washington, D. C. USA.

Energy map., (2011). Renewable biogas for our future environment. Available online at: http://www.energymap.dk/Cache/a4/a42ebb7e682b-45d7-bddf a4e0c1403763.pdf , [Accessed on 27 February 2011].

Gosch, A.; M. Hildegart,; W. Ursula, and J. Walter, (1983). The anaerobic treatment of poultry manure, Animal Res. and Dev., 17: 62-73.

Jagadabhi, P.S., (2011). Methods to enhance hydrolysis during one and two-stage anaerobic digestion of energy crops and crop residues. Jyväskylä University Printing House.

Karakashev, D.; D. Bastone, and I. Angelidaki, (2005). Influence of environmental conditions on methanogenic compositions in anaerobic biogas reactors. Appl Environ Microbiol 71:331-338.

Khanal, S., (2008). Anaerobic biotechnology for bioenergy production: principles and applications, Wiley-Blackwell.

Kuglarz, M.; B. Mrowiec, and J. Bohdziewich, (2011). Influence of kitchen bio-waste addition on the effectiveness of animal manure digestion in continuous condition. - Research and application of 
new technologies in wastewater treatment and municipal solid waste disposal in Ukraine, Sweden and Poland.

Lantz, M.; M. Svensson,; L. Björnsson, and P. Börjesson, (2007). The prospects for an expansion of biogas systems in SwedenIncentives, barriers and potentials, Energy Policy 35 1830-1843.

Lo, K.V.; W.M. Carson and K. Jeffers, 1981. A computer-aided design for biogas production from animal manure. Livestock Wastes. A Renewable Resource, p:133-135, 141.

Mitzalff, K. V., (1988). Engines for biogas. GATEREP. Braunschweig, Germany, p: 27-33.

Ošlaj M. and M. Bogomir, (2010). Biogas as a renewable energy source.

Technical Gazette 17, 1,109-114.

Rashed, M. B.,(2014). The Effect of Temperature on the biogas Production from Olive Pumice. University Bulletin - ISSUE No.16- Vol. (3) July - 2014.

Weiland.p., (2010). Biogas production: current state and perspectives. Appl Microbiol Biotechnol 85:849-860.

Zennaki, B.Z.; A. Zadi,; H. Lamini,; M. Aubinear, and M. Boulif, (1996). Methane Fermentation of cattle manure: effects of HRT, temperature\& substrate concentration.Tropicul tural 14 (4): 134140.

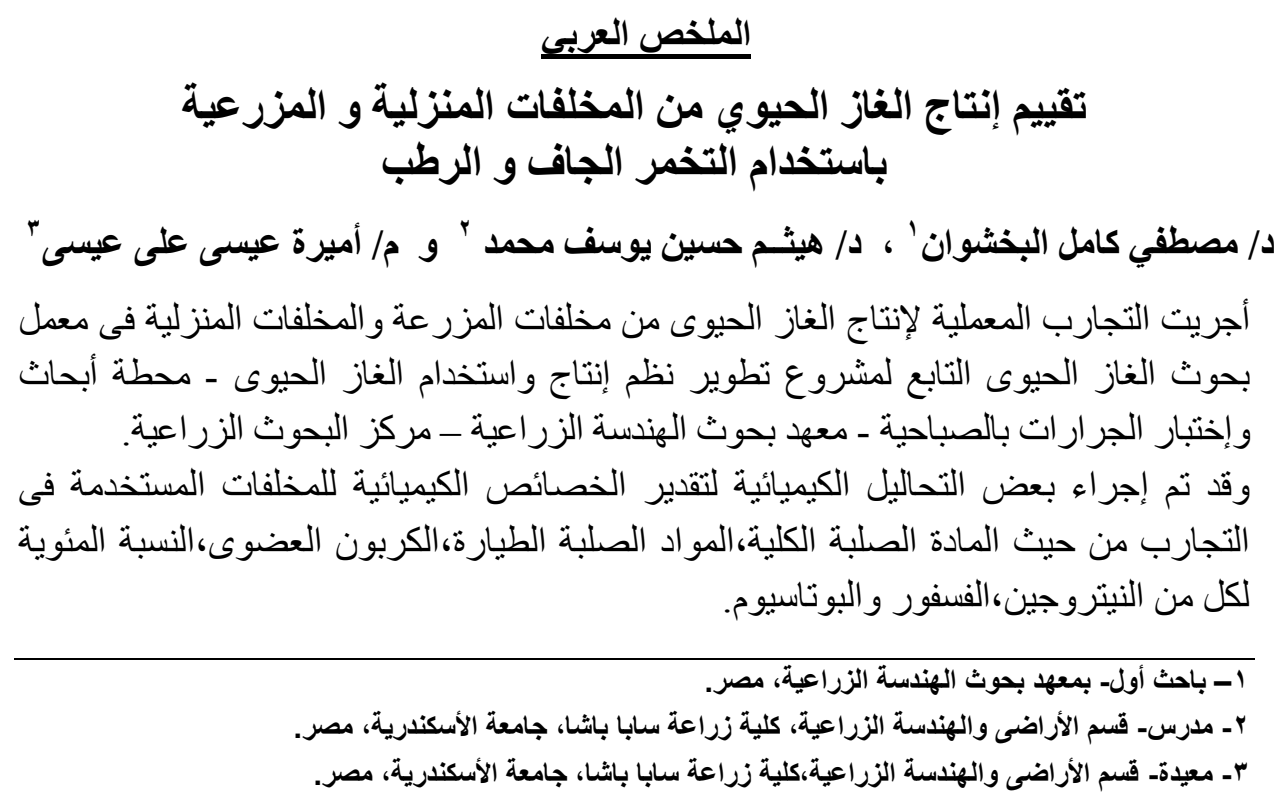


يرهذ هذا البحث إلى تقييم إنتاج الغاز الحيوي الناتج من مخلفات المزرعة والمخلفات المنزلية

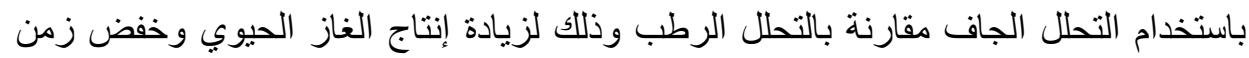

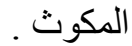
تم دراسة تأثثر درجات الحرارة • ـ و و • ؛ مئوية و درجة الحرارة الجو المحيط على إنتاج الغاز

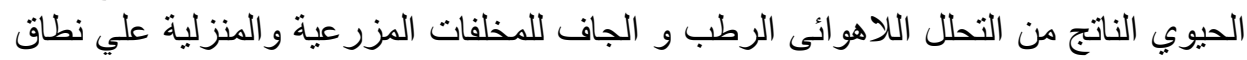
وقد أظهرت النتائج أن أقصى إنتاج تراكمي للغاز الحيوي للتخمر الرطب لرخلفات الرّات المزرعة

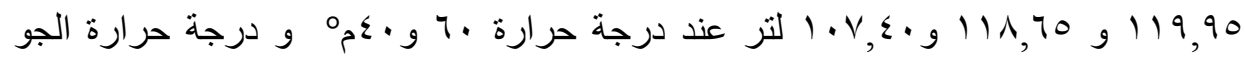

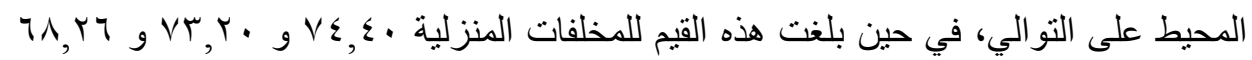

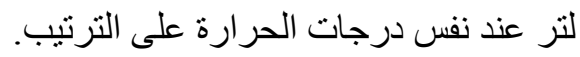

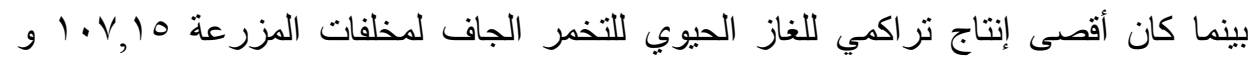

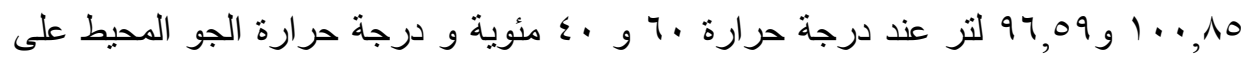

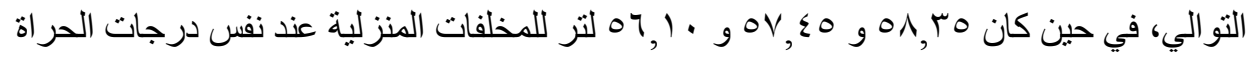

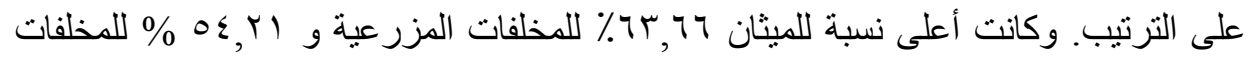

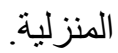

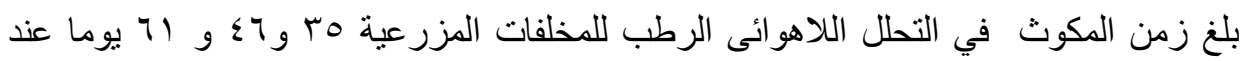

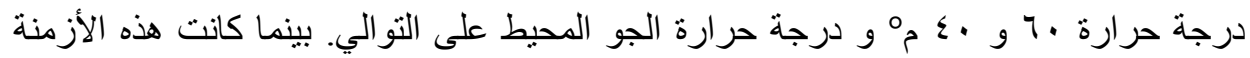

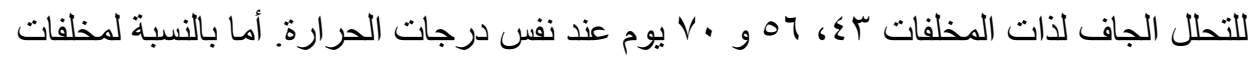

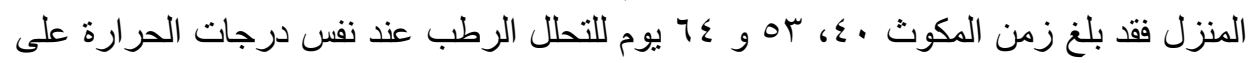

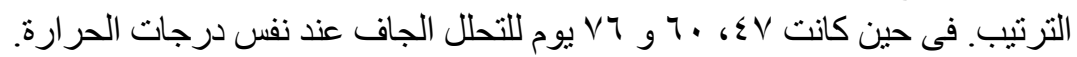

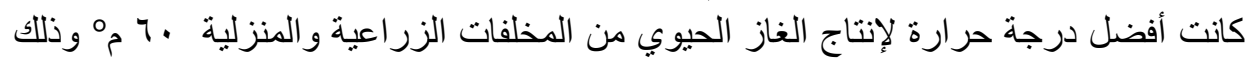

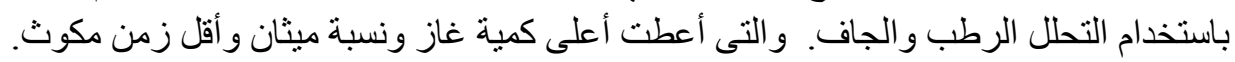

